\title{
A CONCEPTUAL FRAMEWORK OF THE COVID-19 CRISIS MANAGEMENT EFFECTS ON THE EMBEDDED CORPORATE SUSTAINABILITY WITHIN IT\&C-COMPANIES
}

\author{
Adina-Alexandra BRETAN ${ }^{*}$ \\ ${ }^{a}$ Technical University of Cluj-Napoca, Romania
}

DOI: $10.24818 / \mathrm{IMC} / 2020 / 01.05$

\begin{abstract}
The purpose of the paper is to create a conceptual framework for corporate sustainability in the international IT\&C-companies during the Covid-19 pandemic and the crisis generated out of it. It contains a literature review with up-to-date information from both scientific references and web sources. To complete the framework, restrained empirical qualitative research has been also included, identifying and highlighting reactions, measures, and solutions in such corporations. The article addresses a topic of great interest worldwide. It brings value because the literature review and the practical implication build an overview of the crisis management methods met upon the embedded corporate sustainability of the global tech-companies. Information is collected and filtered targeting to offer a certain image of the way this type of companies survived to the SarsCov-2 pandemic. Their crisis management artifices and actions, which, despite the few negative effects cropped out the corporations, gained lots of great knowledge worth saving for future references, found many unusual and unexpected measures and solutions and represent a pylon in the worldwide recovery process. International tech-companies have been both negatively and positively affected by the current crisis, whereas the corporate sustainability has suffered from various changes, depending on the branch and market position of the organization. This type of businesses have reconsidered their priorities, trying to protect their revenue and their employees, even though on a short-term their embedded corporate sustainability importance decreased, hence it did not vanish. Companies still keep this in their core attention and try to find alternatives that will contribute to the well-being of the business.
\end{abstract}

KEYWORDS: embedded corporate sustainability, International IT\&C-Company, Covid-19 crisis, crisis management, pandemic effects

\section{INTRODUCTION}

Over the years, the world has faced many new, unusual and unpleasant situations. Many of them have led to various types of crisis, out of which, with good managerial skills, innovations and implementation of unheard solutions have been developed. Nowadays, looking in the business mirrors, one can see remarkable aspects that rule within international companies and affect the worldwide companies and individuals.

The corporate sustainability is a great strategy used in many international IT-companies with the aim of achieving competitive advantages. The corporate activities are very important in the success of the business, because they involve the relationships with the stakeholders, the creation of social environments and many others, with the purpose of ensuring the ability of enhancements in the embedded corporate sustainability (Herzig \& Schaltegger, 2006).

The crisis management is the field of activity that helps companies with the enabling of crisis typologies and situations, trying to identify the key factors that caused the crisis in the first place

\footnotetext{
* Corresponding author. E-mail address: aadinaabretan@gmail.com
} 
and also which may negatively influence the well-being of the company. The crisis managers analyse the corporate sustainability factors that have both positive and negative effects on the businesses (Flouris \& Yilmaz, 2011).

Considering the current worldwide crisis conte xt, due to the Covid-19 pandemic, the effects on the embedded corporate sustainability in international tech-companies have been both positive and negative, compared to other industries. As Alon (2020) related, the transfer of information is probably the most important pawn in such businesses, that suffered due to the current worldwide crisis. However, it is mentioned, that a solution has been to move the information technology in virtual environments and in virtual realities. This has been a great short-term solution, but of course, as many other sudded taken decisions, some of them have been proved to be considerable long-term or permanent resolutions in a digital era.

\section{BACKGROUND}

Aiming to create a conceptual framework that surrounds the embedded corporate sustainability in globalized tech-companies through a crisis management perspective due to the Covid-19 pandemic, the concepts of actual sustainability and its derivates together with the crisis management theoretical overview, should be firstly thoroughly understood.

\subsection{The Embedded Corporate Sustainability In It\&C-Companies}

The international, global, IT-companies, focus on continuous development, fighting to achieve competitive advantages within their active markets. The ways in which they achieve such goals are mainly different, innovative and unique. One of the most recent strategy of winning competitive advantages, both inside and outside the company, is the sustainability and its derivates met within the business world, such as the corporate and the embedded corporate sustainability.

In order to achieve a complex know-how on a certain topic, a step-by-step approach should be considered. The sustainability should be first of all understood as a whole. According to Montiel \& Delgado-Ceballos (2014) and Spiliakos (2018) the sustainability should be generally approached such as the proper equivalent to the ecological, economic and social goals ratio highlighting its concept among a business. A positive impact is aimed to be created, avoiding the negative possible effects, such as social inequality, environmental issues or even social injustice. On a business level the sustainability implies continuous work on the growth and expansion of the economy, of the prestige, of the services and products quality, stake-and shareholder satisfaction and so on.

An auxiliar often met in the international business world is the corporate sustainability, that creates long-term value on different business levels, such as relationships with stake - and shareholders, employees, customers and so on, as per Benn \& et al. (2014). It is a good strategy used within various speciality spheres. Liu \& Yan (2018) consider that the sustainability within such organization also represents an ethical responsibility, which supports the corporations and therefore the economies, whereas the corporate sustainability represents the value of an organization, defined through the ability of supporting the company's expectations over the time. The corporations are according to Montiel \& Delgado-Ceballos (2014), however, the engine of a contemporaneous lifestyle, that contribute to the wellbeing of the societies among national borders. The concept itself is however quite new in the business dynamic, being generally understood as a „paradigm”, representing the alternative to the traditional business evolution models. Wilson (2003) considers, that the growth is sustained by fulfilling the expectations of the stakeholders, the focus being on the profit maximizing, carefully considering other involved factors in the sustainable, long-term development.

The embedded corporate sustainability is a derived concept out of the standard corporate sustainability approach, that moreover includes more subjects of interest for the business. Dooley (2014) approached its purpose as the decrease the environmental negative impacts and the risks, to reduce the operational expenditure on a short-term basis and therefore the operational costs, to have 
an input in improving the brand image. Whelan \& Fink (2016) and Violo (2018) managed to filter some characteristics out of this approach and to identify their effects on the information technologybased companies. Some of the particularities are: a positive impact on the business performance, low investment, long-term solutions, slow implementation and the fact that they are deeply integrated in the business's performance. Among the effects recognized within such companies, the following can be listed: service and product innovations, strategic intent and partnerships, social and eco innovations, Research and Development (R\&D) corporate assets.

The international IT\&C-companies focused a lot on the embedded corporate sustainability and tried to stand out and to gain competitive advantages by performing various activities in this regard. For example, (Violo, 2018) presented how IBM and Accenture's movements for embedded corporate sustainability got remarked for their proper relevance. IBM has created the Corporate Service Corps initiative for sustaining the talented professionals with the purpose of new strategy enhancement, top talents gathering and recruiting, helping out the competitiveness. Accenture, respectively ADP (Accenture Development Partnerships), has covered hundreds of projects in different countries, considering a fifty percent salary reduction, the other half being covered through NGOs, as a result of taking part in offering business solutions to humanitarian problems.

As per its business benefits, Ceasar (2011) considers the embedded corporate sustainability as a strategy that offers organizations and companies a centralized handle perspective, pursuing efficiency and offering both employees and stakeholders new opportunities among the innovation trend. It is currently being considered one of the best competitive advantages for the international, multinationals and global companies, as mentioned in Innovations (2015). Laszlo \& Zhexembayeva (2017) acknowledge, that in this context the embedding it represents a combination of green products enhancement, sustainable activities of the employees within their business working hours, sustainable life-cycle implementation for both products and services.

\subsection{Covid-19 Crisis Management}

The crisis management has encountered various challenges over the years, each one unique in its own way. The Covid-19 crisis has raised some interesting questions and has unmasked many realities. Industries have been affected, more or less, people have been affected, more or less. The highlight within this paper is how did, especially, the IT\&C - companies and their employees face the pandemic from a business perspective. Seeing the corporate sustainability from a crisis management perspective is quite a challenge, because from a significant advantage, it also became an additional factor that is necessary for the business, but hard to maintain in such times.

It is essential to have an overview of the sustainability strategies involved within the crisis management caused by the Covid-19 pandemic in global tech-companies, in order to understand the unique effects upon the businesses. According to George (2020), a crisis is the opportune time for talk to be tested out. The companies are being constraint by immediate crisis management due to the Covid-19 pandemic. Corporations should support their customers, stakeholders, shareholders, partners, investor and policymakers and should try to link an emergency plan to the new social, financial and environmental requirements (similar to the crisis management strategies applied during the economic crisis in 2008). IT companies worldwide understand the importance of corporate sustainability and try to involve the ESG practices (environmental, social, governance), as an effect of the Covid-19 pandemic. Also, according to Mehra \& et al. (2020), the embedded corporate sustainability in international tech-companies as a crisis management resolution frames a competitive advantage within various markets and information-based branches. Some companies see the sustainability as an added cost and among the cost cutting procedures, implemented by each and every business during the pandemic, tend to withdraw it. As per Haverkamp (George, S., 2020): „No company could have prevented the pandemic, but the reason it is having such a massive effect on supply chains is because we have collectively failed to act on climate, social inequality and biodiversity.” 
Some consider the sustainability as a strategy of the crisis management in the current crisis context. Smith (2020) claims that the sustainability is foreseen to grow and rise in order to help the transformation of the industries all over the world, maybe even play an important role in creating and hosting new ones. All industries are being hardly affected by the current pandemic, natural crisis, one of them, however, basically suffering from an exponential enhancement - the technological areas, the digital industries. Also, as per Liu \& Yan (2018) a positive effect of the Covid-19 crisis in regard to corporate sustainability would be the acceleration of digital transformation, especially AI (artificial intelligence) and machine learning, while another one, according to Chahar (2020) would be the achievement of digital economic ecosystems. Assuming that sustainability and technology go hand in hand, helping out worldwide companies and organizations, as within the sustainability of the worldwide company's operations there have been brough up various opportunities for transformation and innovation.

In reality the actual actions taken as measures by the international technology orientated companies are many, various and mainly innovative, due to the urgent and sudden threat that occurred at that time. Here are some examples of embedded corporate sustainability measures taken by international tech-companies during the pandemic as a crisis management response: social media promotions of brands, products, services have highly increased, maintenance and justification of cash-flow, rebudgeting and cost-cutting, monitoring of all types of business transactions and Inventory activities, more often and more thoroughly, as mentioned by Winarsih \& et.al (2020). As per an analysis of a case study performed by the non-profit organization BSR and GlobeScan (GlobeScan \& BSR, 2020), a strategy consultancy company, involved in one hundred and two different countries, out of various globe regions, in more than twelve job sectors, the following conclusions to the paper's theme have been outlined: the crisis is being considered, both on short-and long-term perspectives, depending on the business's main activities, strategies and aims, on a long-term perspective the Covid-19 crisis might deliberately ask for a stable embedded corporate sustainability or might tend to lead to new expectations and challenges, the most companies however got to short-term resolutions, due to convenience, as a result of the crisis management decisions and measures, implying among other also the cost-cutting strategy, many corporate sustainability activities have been and still are quite affected.

\section{PRACTICAL IMPLICATIONS}

This paper presents a conceptual framework, built on the rocks of literature review, both literature references and web sources, and of a practical involvement created both as a result of personal experience and observations of the author, but also as a result of the quantitative research method chosen as exploration tool within a group of individuals. The purpose of the empirical research has been to gather a group of highly-qualified individuals that professionally act in different ITcompanies and approach them into finding out their personal opinions on the embedded corporate sustainability within the current worldwide context.

\subsection{Impact of the Covid-19 Pandemic on the Embedded Corporate Sustainability}

The corporate sustainability is one of the newest strategies for winning competitive advantages withing various markets and branches. The international IT-companies purchase competitive advantages, trying to always be up to date, to have long-term plans and to the future. There are many processes, work areas and departments within a company, each of them playing an important role regarding the corporate sustainability. The questions nowadays are, however, how have been all these aspects impacted due to the Covid-19 pandemic, how big are the effects, are there both positive and negative outcomes? 


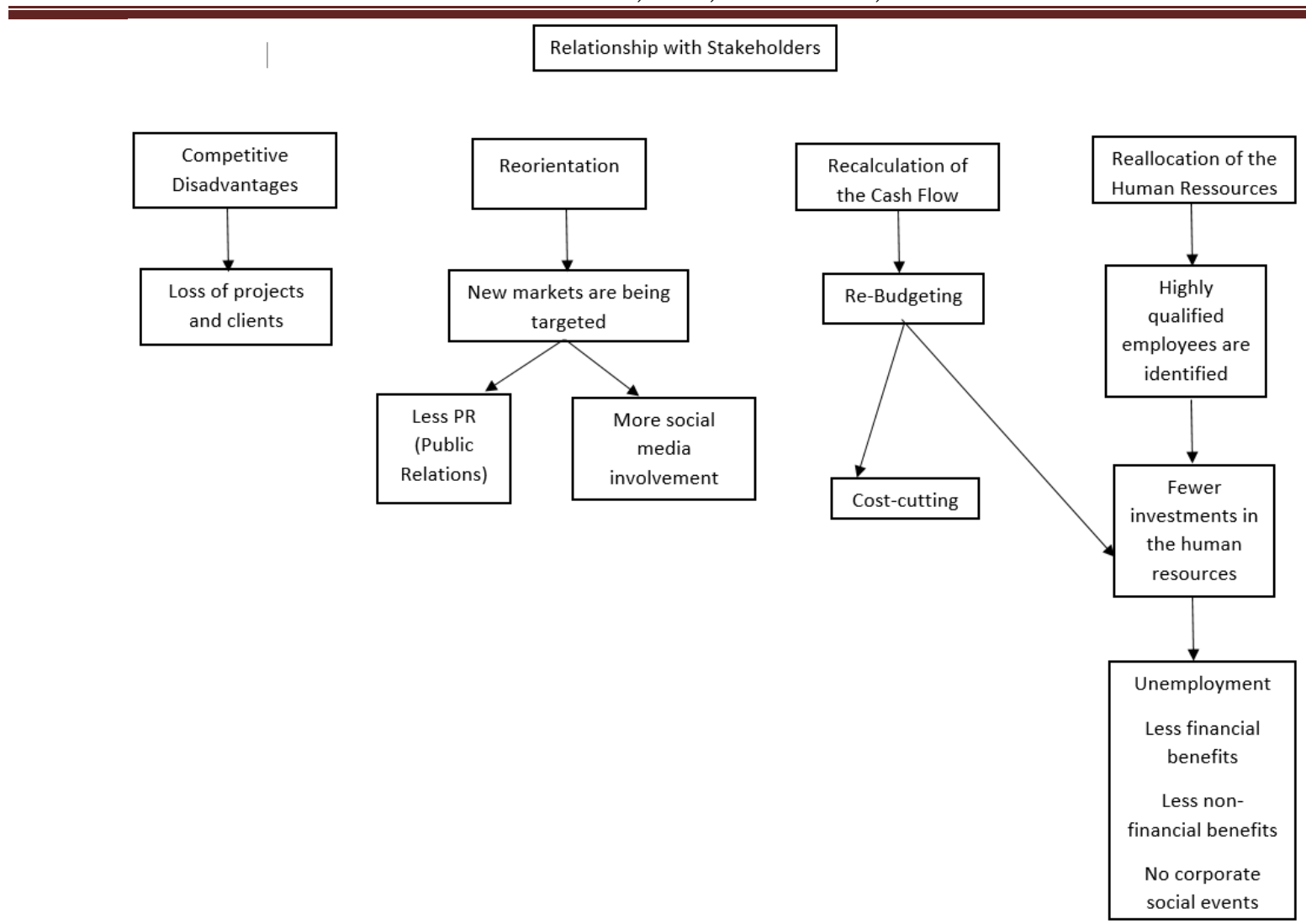

Figure 1. Impacted Areas of the Embedded Corporate Sustainability due to the Covid-19 Crisis

Source: Author's experience and observations

Figure 1 is a graphical representation of the impacted areas within an IT-company with international activities, working on service delivery rather than on own products manufacturing. Beyond the main affected areas, part of the managerial strategies, there are also presented other areas of interest that derive out of the main ones and that are also more or less affected.

- Competitive advantages: due to the crisis, within the service outsourcing branch, the clients tried to reorientate themselves to „best deals”: cheaper, promising, rather than continuing to work with well-known companies with which they already have a remarkable business past and many positive outcomes. This constatation lead to project and maybe also client loss.

- Reorientation: due to the competitive disadvantages that came out of the Covid-19 crisis many global tech-companies tried to find new paths, such as new industries, new clients, new technologies, targeting new markets. What is more, they tried to identify some lowbudget solutions for promotions, rather than the ones used before, which lead many of them to social media public relations.

- Recalculation of the cash-flow: most of the international, global IT-companies, are stable enough for the moment and maybe for the next few years. The main problem, however, is that the future has to be built in the past. This means, that such companies try their best to survive and overcome the current Coronavirus crisis as soon and as good as possible, because the current business (new contracts, old and new clients, specialists and so on) is the base of the pyramid that will exist in the next five years. Because of this these types of organizations took urgent and drastic measures, such as cost-cutting (no social events, no bonuses, no wage raises etc.) and unfortunately many of them stopped investing in their core resource - their employees.

- Reallocation of the human resources: a good manager and a good CEO know that the core of each and every business are the employees, the human resources. A company without great 
specialists, highly qualified individuals, cannot succeed as much as they could ever wish for. This is one of the reasons why, despite the drastic measures that have been taken as part of the managerial strategy for avoiding disastrous risks, this type of organizations try to identify their best employees and take advantage of their skills. What is more, many of them, would rather cut some of the financial or non-financial benefits, rather than resort to unemployment.

\subsection{Crisis Management of the Impacted Areas of the Corporate Sustainability}

The Covid-19 pandemic has led to great and diverse negative effects within each and every industry worldwide. As every branch, market and business sector are different from another, directly dependent on their areas of interest and of activity, this paper focuses mainly on the digital business sector, namely on the IT-companies. This branch has implied by its nature some measures than have been considered and implemented within many companies worldwide, as crisis management strategies. The following table presents the approach taken within the affected areas identified before by such organizations.

Tabel 1. Crisis Management of the Impacted Areas of the Corporate Sustainability in IT-Companies

\begin{tabular}{|l|l|l|}
\hline \multicolumn{1}{|c|}{ Afected Areas } & $\begin{array}{l}\text { Level of } \\
\text { the Crisis }\end{array}$ & \multicolumn{1}{|c|}{ Managerial Approach } \\
\hline $\begin{array}{l}\text { Relationship with } \\
\text { Stakeholders }\end{array}$ & High & $\begin{array}{l}\text { The crisis has highly impacted the relationships with the } \\
\text { stakeholders, because everyone is looking after better deals, } \\
\text { that in the current context are hardly achieved }\end{array}$ \\
\hline $\begin{array}{l}\text { Competitive } \\
\text { Disadvantages }\end{array}$ & Neutral & $\begin{array}{l}\text { All the tech-companies have been affected by this crisis, they } \\
\text { all took many innovative and sudden measures and they all } \\
\text { suffered more or less of losses }\end{array}$ \\
\hline $\begin{array}{l}\text { Loss of projects } \\
\text { and clients }\end{array}$ & High & $\begin{array}{l}\text { Many IT-companies, mostly the ones that focus on service } \\
\text { outsourcing lost many projects and clients due to low } \\
\text { convenience of contracts and difficult negotiations }\end{array}$ \\
\hline Reorientation & High & $\begin{array}{l}\text { The service orientated IT-organizations aim many different } \\
\text { markets, as the digital sector has a very wide portfolio }\end{array}$ \\
\hline $\begin{array}{l}\text { New markets are } \\
\text { being targeted }\end{array}$ & $\begin{array}{l}\text { As the technology is one of the few areas that suffered from an } \\
\text { exponential development as an effect of the pandemic, many } \\
\text { industries, sectors and markets aim to reorientate themselves } \\
\text { towards information technology }\end{array}$ \\
\hline $\begin{array}{l}\text { Less PR (Public } \\
\text { Relations) } \\
\text { the Cash Flow }\end{array}$ & High & $\begin{array}{l}\text { Due to both social distancing measures imposed by the } \\
\text { government and cost-cutting measures the companies decided } \\
\text { that the current liquid capital and assets must be protected, so } \\
\text { they invest less than ever in the public relations and advertising }\end{array}$ \\
\hline involvement & High & $\begin{array}{l}\text { As the investment in the PR, advertising and marketing as a } \\
\text { whole decreased substantially, many digital orientated } \\
\text { companies identified new ways to promote their businesses, } \\
\text { with less effort, resources and money. }\end{array}$ \\
\hline $\begin{array}{l}\text { In order to create a stable base of the business pyramid for the } \\
\text { upcoming years, these companies decided to recalculate the } \\
\text { whole cash-flow transactions and carefully protect their } \\
\text { revenues. }\end{array}$ \\
\hline
\end{tabular}




\begin{tabular}{|c|c|c|}
\hline Afected Areas & $\begin{array}{l}\text { Level of } \\
\text { the Crisis }\end{array}$ & Managerial Approach \\
\hline $\begin{array}{l}\text { Re-Budgeting and } \\
\text { cost-cutting }\end{array}$ & High & $\begin{array}{l}\text { This are two of the most modern and standard crisis } \\
\text { management strategies used within the current pandemic } \\
\text { context. }\end{array}$ \\
\hline $\begin{array}{l}\text { Reallocation of the } \\
\text { Human Resources } \\
\text { and identification } \\
\text { of highly qualified } \\
\text { employees }\end{array}$ & Neutral & $\begin{array}{l}\text { In order to avoid unemployment, because most of these } \\
\text { companies play on high business levels and understand the } \\
\text { importance of their employees, they tried mainly to identify } \\
\text { their strengths in order ro reallocate them where needed and } \\
\text { bring value to the current projects. }\end{array}$ \\
\hline $\begin{array}{l}\text { Fewer investments } \\
\text { in the human } \\
\text { resources }\end{array}$ & Neutral & $\begin{array}{l}\text { Despite the fact that many companies tried to avoid the } \\
\text { unemployment and tried to reallocate them when and where } \\
\text { needed, they did not invest within the human resources as } \\
\text { much as they did before. Their attention and main focus have } \\
\text { been on overcoming the crisis as better as possible, with few } \\
\text { inputs in each process of the company. }\end{array}$ \\
\hline $\begin{array}{l}\text { Less financial } \\
\text { benefits } \\
\text { Less non-financial } \\
\text { benefits } \\
\text { No corporate social } \\
\text { events }\end{array}$ & High & $\begin{array}{l}\text { Some of the measures implemented by these companies has } \\
\text { been, as mentioned before, the cost-cutting and re-budgeting, } \\
\text { which lead to redesign of benefits, both financial and non- } \\
\text { financial, of the employees. }\end{array}$ \\
\hline
\end{tabular}

Source: Author's experience, observations and peer review

Table 3 frames the identified areas within an international, service-orientated IT-company, that have been affected by the Covid-19 crisis with a unique approach based on the experience and personal observations of the author, but also due to the established results as part of the empirical research. It highlights the impact that has covered some specific areas and approaches each constatation.

\subsection{Results of the Empirical Research}

The empirical research within this paper represents in fact a quantitative research tool in the sphere of embedded corporate sustainability in international IT-companies, from a Covid-19 crisis management perspective. For this study, the target group has been set and a survey, directly dependent on the individuals' characteristics, was created. It contained nine different questions addressed to the paper's theme. The survey has been shared to ten individuals, with ages between 25 and 30 years old, which professionally activate in seven different IT-companies. The aim was to identify the differences between as many companies as possible. The surveys have been fulfilled online, due to social distancing safety measures. The peer feedback was analysed during the aftermath and the results were explained and in table form and in a pie-chart representation highlighted. 


\section{Table 2. Covid-19 effects on the corporate sustainability of the tech-companies highlighted as peer feedback results}

\begin{tabular}{|c|c|c|}
\hline Area of interest & Employee personal perception & Percentage (\%) \\
\hline $\begin{array}{l}\text { Employee satisfaction } \\
\text { with the company's } \\
\text { reaction to the Covid-19 } \\
\text { crisis }\end{array}$ & $\begin{array}{l}\text { Most of the approached employees showed a } \\
\text { high satisfaction level }\end{array}$ & $\begin{array}{l}\text { - } 60 \% \text { are very satisfied } \\
-30 \% \text { are satisfied } \\
-10 \% \text { are not satisfied at all }\end{array}$ \\
\hline $\begin{array}{l}\text { The corporate } \\
\text { sustainability has been } \\
\text { affected by the Covid-19 } \\
\text { pandemic, based on the } \\
\text { employee's opinions }\end{array}$ & $\begin{array}{l}\text { Less than a half of the questioned individuals } \\
\text { consider that the current crisis affected the } \\
\text { corporate sustainability in the II-company } \\
\text { where they work, where the majority did not } \\
\text { remark a great impact }\end{array}$ & $\begin{array}{l}\text { - } 60 \% \text { did not observe a big } \\
\text { impact } \\
\text { - } 40 \% \text { experienced the negative } \\
\text { effects }\end{array}$ \\
\hline $\begin{array}{l}\text { The high-qualified } \\
\text { specialists find the } \\
\text { corporate sustainability as } \\
\text { a competitive advantage }\end{array}$ & $\begin{array}{l}\text { All of the people gathered within this study } \\
\text { find the sustainability within a company a great } \\
\text { competitive advantage }\end{array}$ & $\begin{array}{l}100 \% \text { agree that the corporate } \\
\text { sustainability can be a } \\
\text { competitive advantage within } \\
\text { various markets }\end{array}$ \\
\hline $\begin{array}{l}\text { Among the focuses } \\
\text { of the international } \\
\text { tech-companies the } \\
\text { corporate sustainability } \\
\text { is also an important actor }\end{array}$ & $\begin{array}{l}\text { Most of the questioned employees think that } \\
\text { the company where are professionally act } \\
\text { focuses on protecting and improving the } \\
\text { corporate sustainability }\end{array}$ & $\begin{array}{l}\text { - } 60 \% \text { agree that the company } \\
\text { has the corporate sustainability } \\
\text { as a main focus } \\
-40 \% \text { find other aspects prior } \\
\text { on the list of main focuses }\end{array}$ \\
\hline $\begin{array}{l}\text { The perception } \\
\text { of the questioned } \\
\text { tech-specialists on the } \\
\text { presence of competitive } \\
\text { advantages in their } \\
\text { companies }\end{array}$ & $\begin{array}{l}\text { Very few persons, each from different } \\
\text { companies, considered that the companies } \\
\text { where they work does not own such a } \\
\text { competitive advantage within their market }\end{array}$ & $\begin{array}{l}-70 \% \text { confirm that they } \\
\text { remarked the competitive } \\
\text { advantages of their companies } \\
\text { - } 30 \% \text { cannot identify such } \\
\text { advantages in comparison with } \\
\text { their branch competitors }\end{array}$ \\
\hline $\begin{array}{l}\text { Employee's perception of } \\
\text { weather their company } \\
\text { promote the concept of } \\
\text { embedded corporate } \\
\text { sustainability }\end{array}$ & $\begin{array}{l}\text { All the peer feedback resulted into agreeing } \\
\text { with the fact that the concept itself is being } \\
\text { highly promoted, however, it is not necessarily } \\
\text { also implemented }\end{array}$ & $\begin{array}{l}100 \% \text { consider that the concept } \\
\text { itself is being promoted within } \\
\text { their company }\end{array}$ \\
\hline $\begin{array}{l}\text { The Covid-19 pandemic } \\
\text { has already affected, } \\
\text { more or less, the } \\
\text { corporate sustainability }\end{array}$ & $\begin{array}{l}\text { One of the many effects of the current crisis } \\
\text { has also has an impact over the sustainability } \\
\text { promoted within the international IT- } \\
\text { companies }\end{array}$ & $\begin{array}{l}\text { - } 80 \% \text { of the specialists can see } \\
\text { the effects of the pandemic } \\
\text { - 20\% did not remark high } \\
\text { effects }\end{array}$ \\
\hline
\end{tabular}

Source: Peer feedback analysis as a result of the empirical, quantitative research performed by the author 


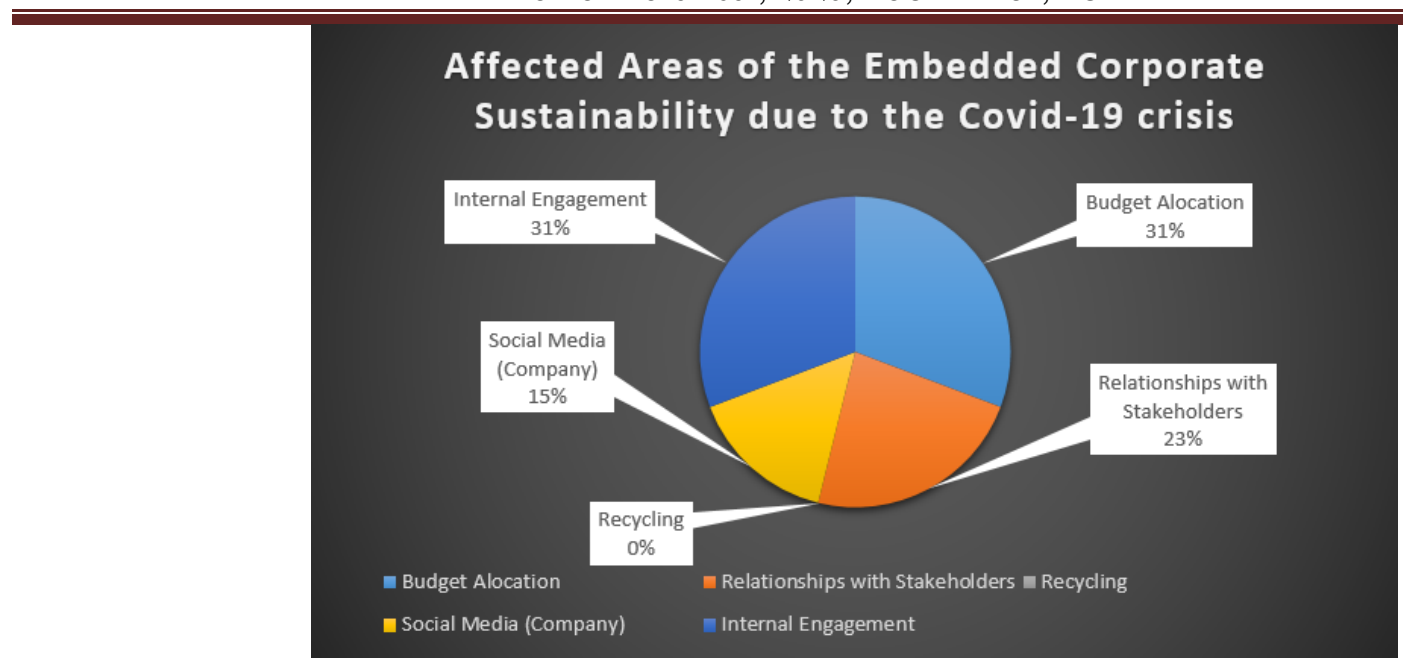

Figure 2. Affected areas of the embedded corporate sustainability due to the Covid-19 crisis Source: Author's representation based on the peer feedback results

As per figure 10, the process areas that have been affected once with the Covid-19 crisis are numerous, but each and every one has been more or less affected by the unusual situation. In this pie chart one can remark, that most of the employees have observed changes in the internal engagement and budget allocation, which shows that this type of companies tried to take advantage of their high-skilled employees and tried to carefully alocate the budgets, instead of choosing unemployment as an emergency strategy. On the next level, out of the choosen areas, is situated the relationship with stakeholders. Many employeed have had the chance to note that the relationships between their company and different stakeholders is not the same, due to hard negotiations, inconvinience and probably missunderstandings. Afterwards, it is outstanding that, as part of the cost-cutting, budget re-allocation strategy, the company decreased their investments in PR (public relations) and advertising, but did however find less expensive methods, such as the social media. Regarding recycling, as part of the embedded corporate sutainability, one can conclude that this has not been affected at all. The companies continue their green work and try to overcome the unusual and unexpected situation, not make it worst.

\section{CONCLUSIONS}

Nowadays, the information technology branch plays a significant role in the evolution of the businesses and of the world. The companies that work within this industry try to cover as many areas of interest, out of various different markets, as possible. Many focusses themselves on delivery of shared-services, while other on own product manufacturing. The differences between them exist, on an operational level and on a strategic level, but the support processes are quite similar. Among the support processes of an international IT\&C-company can be many auxiliar areas mentioned, such as finance, health, local IT-support, facility, marketing and so on. Each of these areas and many others have their own strategies and their own targets. The corporate sustainability is one of the strategies used within the facility and marketing support processes within such a corporation.

The embedded corporate sustainability is a manoeuvre implemented within international techcompanies not long ago, but ever since the management of these companies has remarked lots of competitive advantages, such as employee satisfaction, high-specialized employees, great advertisment and a better placement within the targeted markets, improvement of brand and image, maximized profit and so on. As this strategy has brought over the last years so many corporate 
advantages, the companies worked more and more around this subject, in order to implement as many topics as possible and gain great visibility worldwide.

Ever since the appearance of the new coronavirus Sars-Cov2, things have changes drastically in every industry, worldwide. No one has been spared of the devastating effects of the declared pandemic. Regarding the international IT\&C-companies', studies have been performed and are, however, furthermore being development, hence the effects continue to appear, either negative, or in isolated cases, positive.

The international IT-companies, both shared service orientated and own product manufacturers, have also suffered because of the effects. As per the developed case study based on peer review, the results show that all of the employees, out of various companies, remarked the impacts of the crisis within their corporations. They showed themselves, however, satisfied with the reactions of the companies, with the measures taken and imposed by them and by the way the management dealt with the whole new and unexpected situation. Most of them consider that the corporate sustainability is one of the main focuses of the companies, but it is more or less affected by the pandemic, as part of the crisis management. The measures and the decisions implemented as a result of the pandemic crisis management have been many, affecting each and every process within the company. The corporate sustainability has been, unfortunately touched by the changes, in comparison with the past image, hence not dissolved. The big companies considered that by protecting their revenue and their good employees and of course by cost-cutting and re-budgeting where possible, the future should be, at least on a short-term, safe. Because of this, the responsible departments of these organizations managed to find out alternatives for the corporate sustainability, in order to keep it alive and not loose great advantages built in years. Due to the sudden threat that appeared worldwide, companies actioned similar, but yet different. The particularities of each company, even though it performs its activities in the same industry, lead to different measures and decisions. These characteristics that define the IT\&C-companies are interesting to analyse, because some of them decreased the investment in the corporate sustainability, targeting other strategies and processes, while others kept it on their main list. The values and the goals of each company, despite the industry, are different, which leads to a great diversity within the business world.

Managing sustainable organizations is not an easy thing to do. The big corporations require great leaders and managers, divided granularly within various areas of interest, that have the ability and the power to show courage when needed.

\section{REFERENCES}

Alon, l. (2020, May 27). Covid19 and International Business: A Viewpoint. ARCS. Retrieved on July 2020 from: https://corporate-sustainability.org/covid19-and-international-business-aviewpoint/

Benn, S., Edwards, M., Williams, T. (2014). Organizational Change for Corporate Sustainability. Abingdon: Routledge.

Ceasar, N. (2011). Embedded sustainability - the next big competitive advantage? The Guardian.

Chahar, D. (2020). The Impacts of COVID-19 on Sustainability and Technology. readwrite. Retrieved on August 2020 from: https://readwrite.com/2020/06/06/the-impacts-of-covid-19-onsustainability-and-technology/

Dooley, K. (2014). Organisational Behaviour: Business Models for a Profitable and Sustainable Future. Research Gate, 248-254.

Flouris, T. G. \& Yilmaz, A. K. (2011). Risk Management and Corporate Sustainability in Aviation. USA: MPG Books Group.

George, S. (2020). WBA: Companies with embedded sustainability best-placed to weather coronavirus storm. Edie. Retrieved on August 2020 from: https://www.edie.net/news/7/WBA-Companies-with-embedded-sustainability-are-best-placed-to-weather-the-coronavirus/ 
GlobeScan \& BSR (2020). Corporate Sustainability \& COVID-19 Pulse Poll of SustainabilityFunctions:SummaryFindings. Retrieved on August 2020 from bsr.org: https://www.bsr.org/files/general/Impact_of_Covid-19_on_Sust_Function_Survey_Final.pdf

Herzig, C. \& Schaltegger, S. (2006). Corporate Sustainability Reporting. An Overview. Dordrecht: Springer.

Winarsih, Indriastuti, M., \& Fuad, K. (2020). Impact of Covid-19 on Digital Transformation and Sustainability in Small and Medium Enterprises (SMEs): A Conceptual Framework. Complex, Intelligent and Software Intensive Systems: Proceedings of the 14th International Conference on Complex, Intelligent and Software Intensive Systems (CISIS-2020), 1194, 471-476. https://doi.org/10.1007/978-3-030-50454-0_48

Innovations Adec (2015). How Tech Companies are Promoting Sustainability. Retrieved on July 2020 from www.esg.adec-innovations.com: https://www.esg.adecinnovations.com/resources/newsletters/september-2015-how-tech-companies-are-promotingsustainability/how-tech-companies-are-promoting-sustainability/

Laszlo, C. \& Zhexembayeva, N. (2017). Embedded Sustainability: The Next Big Competitive Advantage. New York: Routledge.

Liu, S. \& Yan, M.R. (2018). Corporate Sustainability and Green Innovation in an Emerging Economy-An Empirical Study in China. MDPI, 29.

Mehra, N., Yau, I., Kwok, I. (2020). COVID-19 could be catalyst for ESG adoption by tech companies, finds KPMG analysis. KPMG. Retrieved on July 2020 from: https://home.kpmg/cn/en/home/news-media/press-releases/2020/05/covid-19-could-be-catalystfo-esg-adoption-by-tech-companies.html

Montiel, I. \& Delgado-Ceballos, J. (2014). Defining and Measuring Corporate Sustainability: Are We There Yet? ResearchGate, 8.

Smith, K. (2020). Sustainability and tech post COVID-19. KPMG. Retrieved on July 2020 from: https://home.kpmg/xx/en/blogs/home/posts/2020/07/looking-to-the-future-from-collision2020.html

Spiliakos, A. (2018). What does "Sustainability" Mean in Business? Harvard Business School Online. Retrieved on July 2020 from: https://online.hbs.edu/blog/post/what-is-sustainability-inbusiness

Violo, M. (2018). 25 companies carrying out corporate social innovation. siX. Retrieved on July 2020 from: https://socialinnovationexchange.org/insights/25-companies-carrying-outcorporate-social-innovation

Whelan, T. \& Fink, C. (2016). The Comprehensive Business Case for Sustainability. Harvard Business Review.

Wilson. (2003). Corporate Sustainability: What is it and where does it come from? IVEY Business Journal. Retrieved on July 2020 from: https://iveybusinessjournal.com/publication/corporatesustainability-what-is-it-and-where-does-it-come-from/ 